\title{
Możliwości komplementarnego wykorzystania gazu ziemnego i odnawialnych źródeł energii
}

\begin{abstract}
Przedmiotem artykułu jest określenie możliwości stosowania gazu ziemnego jako nośnika energetycznego, uzupełniającego wykorzystanie odnawialnych źródeł energii. Przedstawiono światowe tendencje w zakresie rozwoju niestabilnych źródeł energii odnawialnej. Omówiono rozwiązania zapewniające komplementarność gazu ziemnego z odnawialnymi źródłami energii i uwarunkowania współpracy systemów elektroenergetycznego oraz gazowego. Poddano analizie perspektywy wdrożenia komplementarnych technologii wykorzystujących gaz ziemny i OZE w Polsce w aspekcie obowiązujących, a także prawdopodobnych przyszłych regulacji prawnych.
\end{abstract}

Słowa kluczowe: odnawialne źródła energii, gaz ziemny, energia wiatrowa, energia słoneczna, komplementarność, synergia.

\section{The possibility of complementary use of natural gas and renewable energy sources}

The subject of the article is to present the possibility of using natural gas as an energy carrier supplementing the use of renewable energy sources. The world trends in the development of unstable renewable energy sources are presented. Solutions to ensure the complementarity of natural gas with renewables and conditions for the cooperation of the electricity and gas systems are discussed. An analysis was made of the prospects for the implementation of complementary technologies using natural gas and RES in Poland in terms of present and probable future legal regulations.

Key words: renewables, natural gas, solar power, wind power, complementarity, synergy.

\section{Wprowadzenie}

W związku z międzynarodowymi zobowiązaniami, mającymi na celu obniżenie emisji dwutlenku węgla i innych gazów cieplarnianych, a także dążeniem poszczególnych państw do uniezależnienia się od importu paliw kopalnych, wzrasta udział odnawialnych źródeł energii w globalnym bilansie energetycznym. Coraz większy procent energii odnawialnej jest generowany z wykorzystaniem odnawialnych źródeł energii o zmiennej wydajności. W związku z tym, rośnie zapotrzebo- wanie na magazynowanie nadwyżek energii, a także pojawia się konieczność przewidywania pracy rezerwowych źródeł energii oraz stosowania komplementarnych nośników energetycznych. Tę rolę może efektywnie spełniać gaz ziemny ze względu na możliwość elastycznego stosowania. Gaz ziemny jest także nośnikiem w pełni komplementarnym z biometanem, będącym jednym z odnawialnych źródeł energii, powstającym w procesie przetwarzania biomasy.

\section{Przesłanki komplementarności gazu ziemnego i odnawialnych źródeł energii w miksie energetycznym}

Strategia synergii gazu ziemnego i odnawialnych źródeł energii opiera się na przesłankach wynikających zarówno z możliwości zastosowania gazu ziemnego jako elastycznego źródła do uzupełniania energii produkowanej przez niestabilne źródła odnawialne, jak i z traktowania odnawialnego źródła energii - gazu z fermentacji biomasy - jako paliwa w części lub całkowicie, w zależności od przeprowadzonych procesów uzdatniania, komplementarnego z gazem ziemnym. Za przykład komplementarności odnawialnych źródeł energii i gazu ziemnego, łączący powyższe możliwości, można uznać technologię Power-to-Gas, polegającą na wykorzystaniu nadwyżek energii z niestabilnych odnawialnych źródeł do produkcji 
wodoru w procesie elektrolizy, a następnie wytworzeniu metanu w procesie syntezy wodoru $\mathrm{z}$ dwutlenkiem węgla pochodzącym ze źródeł biologicznych.

Odnawialne źródła energii zwiększają swój udział w globalnym bilansie energetycznym. Z raportu agendy ONZ REN21 (Renewable Energy Policy Network for the $21^{\text {st }}$ Century) [14] wynika, że odnawialne źródła energii w roku 2015 odpowiadały za zaspokojenie 19,3\% globalnego zapotrzebowania na energię. Osiągnięto to głównie dzięki programom wsparcia i promowania OZE, które wdraża ponad 160 krajów, aby spełnić zobowiązania dotyczące niższych emisji dwutlenku węgla albo uniezależnić się od importu ropy i gazu.

Pomimo średniego rocznego światowego wzrostu PKB o $3 \%$ i konsumpcji energii o 1,5\%, trzeci rok z rzędu globalna emisja dwutlenku węgla związana z energią pochodzącą z paliw kopalnych i przemysłu niemal nie ulega zmianie, wzrastając jedynie o $0,2 \% \mathrm{w}$ skali roku, w porównaniu ze średnim rocznym wzrostem wynoszącym $2,2 \% \mathrm{w}$ poprzedniej dekadzie. Spowolnienie wzrostu emisji spowodowane było głównie spadkiem wykorzystania węgla na świecie, ale również poprawą efektywności energetycznej oraz zwiększeniem wytwarzania energii ze źródeł odnawialnych.

Mimo niesprzyjających rynkowi OZE stosunkowo niskich globalnych cen paliw kopalnych, w ostatnich latach nastąpiły zmiany, które mają korzystny wpływ na rozwój sektora energii odnawialnej, takie jak znaczące obniżki cen niektórych technologii energii odnawialnej (zwłaszcza wykorzystania energii słonecznej i energii wiatrowej) oraz dalszy rozwój technologii $\mathrm{w}$ dziedzinie magazynowania energii.

W sektorze produkcji energii elektrycznej w 2016 roku odnotowano roczny wzrost mocy zainstalowanej w źródłach energii odnawialnej oszacowany na $161 \mathrm{GW}$. Łączna moc ze źródeł odnawialnych wzrosła prawie o $9 \% \mathrm{w}$ porównaniu z rokiem 2015 , do blisko 2017 GW na koniec roku 2016. Rekordowy wzrost nastąpił w fotowoltaice, gdzie po raz pierwszy moc nowo zainstalowanych urządzeń (pomniejszona o moc urządzeń wycofanych z eksploatacji) była większa, niż w przypadku jakiejkolwiek innej technologii wytwarzania energii odnawialnej. Fotowoltaika stanowiła około $47 \%$ nowo zainstalowanej mocy odnawialnej w 2016 roku, energia wiatrowa - około 34\%.

Energia odnawialna jest wykorzystywana również do zaspokojenia zapotrzebowania na ciepło i chłodzenie dzięki zasobom energii słonecznej, geotermalnej lub biomasy (stałej, ciekłej i gazowej). W sektorze ogrzewania nośnikiem OZE o niestabilnej produkcji, potencjalnie wymagającym źródła uzupełniającego jest słońce. W globalnym bilansie energia słoneczna stanowi około $8 \%$ energii odnawialnej zużytej na cele grzewcze (dominuje bioenergia - około 90\%).

Kolejnym sektorem, w którym wykorzystuje się odnawialne źródła energii jest transport. Zastosowanie energii odna- wialnej w transporcie wynika z użycia biopaliw ciekłych lub biopaliw zmieszanych z paliwami konwencjonalnymi, użytkowania pojazdów z napędem gazowym i wykorzystania infrastruktury tankowania, która może być zasilana gazem biologicznym oraz elektryfikacji transportu z odnawialnych źródeł energii elektrycznej. Najbardziej znaczącą część energii odnawialnej stanowią biopaliwa (etanol i biodiesel). Nadal istnieją pewne bariery rozszerzenia udziału biogazu w sektorze transportu, w tym brak regulacji dotyczących dostępu do sieci gazu ziemnego, brak infrastruktury gazowej, zdecentralizowany charakter produkcji biogazu i stosunkowo wysokie koszty. Większa część produkcji biogazu przeznaczonej do celów transportowych koncentruje się w Europie i Stanach Zjednoczonych.

Sytuację sektora OZE, w odniesieniu do niestabilnych źródeł, można ocenić, rozpatrując przede wszystkim stan rozwoju wytwarzania energii ze słońca i z wiatru. W 2016 roku przybyło około $75 \mathrm{GW}$ mocy zainstalowanej w ogniwach fotowoltaicznych na świecie. Do końca roku 2016 globalna moc fotowoltaiczna wyniosła około $303 \mathrm{GW}$. Krajami o największej produkcji energii z ogniw fotowoltaicznych są: Chiny, Japonia, Niemcy, Stany Zjednoczone oraz Włochy. Wzrost rynku spowodowany był rosnącą konkurencyjnością cenową ogniw fotowoltaicznych, a także rosnącym zapotrzebowaniem na energię elektryczną i poprawą świadomości ekologicznego potencjału energii słonecznej. W roku 2016 przekroczono granicę 100 GW mocy zainstalowanej w fotowoltaice w Unii Europejskiej. Do końca 2016 roku w UE było 106 GW zainstalowanej mocy fotowoltaicznej, ponad 32 razy więcej niż 10 lat wcześniej. Oprócz produkcji prądu w ogniwach fotowoltaicznych energia słoneczna jest także szeroko stosowana w celu dostarczenia ciepłej wody, ogrzewania i chłodzenia, suszenia produktów oraz zapewnienia ciepła, pary lub chłodzenia w procesach przemysłowych z wykorzystaniem kolektorów słonecznych. Pod koniec 2016 roku instalacje ogrzewania słonecznego zostały wykorzystane w co najmniej 127 krajach. Łączna moc zainstalowana kolektorów wzrosła w roku 2016 do $456 \mathrm{GW}$ w porównaniu z $435 \mathrm{GW}$ w roku 2015.

$\mathrm{W}$ sektorze energii z wiatru, przyrost nowo zainstalowanej mocy w elektrowniach wiatrowych wyniósł w roku 2016 $55 \mathrm{GW}$, a całkowita moc zainstalowana na koniec 2016 $487 \mathrm{GW}$ (roczny wzrost o 12\%) [5].

Źródła energii odnawialnej o zmiennej, zależnej od warunków pogodowych produkcji - energia słoneczna i wiatrowa mają ponad $75 \%$ udziału w nowo instalowanej mocy w ostatnich latach. Tak duży udział w produkcji ciepła i systemie elektroenergetycznym stwarza zagrożenie stabilności oraz bezpieczeństwa energetycznego. Gaz ziemny jest źródłem, które ze względu na elastyczność stosowania dobrze nadaje się do kompensowania niedoborów i przejmowania nadwyżek energii, 
zarówno jako bezpośrednie źródło rezerwowe, jak i nośnik energetyczny, umożliwiający magazynowanie energii.

Drugim obszarem komplementarności gazu ziemnego i źródeł energii odnawialnej jest wykorzystanie biogazu. Biogaz, w zależności od zastosowanych metod uzdatniania może być całkowicie lub częściowo komplementarny z biogazem i użytkowany z wykorzystaniem infrastruktury gazu ziemnego zarówno w sektorze gazownictwa, energii elektrycznej, jak i transportu.

Z analizy ostatnich trendów za rok 2016 przedstawionych w raporcie REN 212017 [14] wynika, że rynek biogazu jest dość stabilny, a jego rozwój odnotowuje się głównie w krajach rozwiniętych. Większość biogazu produkowana jest w Stanach Zjednoczonych, gdzie surowcem są przede wszystkim odpady zdeponowane na składowiskach oraz w Europie. Produkcja w Europie koncentruje się na fermentacji beztlenowej odpadów rolnych, w tym gnojowicy zwierzęcej, a także coraz częściej na fermentacji odpadów spożywczych (głównie w Szwecji i Wielkiej Brytanii).

Wzrost liczby biogazowni w Europie wyniósł od około 6000 w 2009 roku do prawie 17000 w 2015 roku [4]. Ponie- waż istnieje duża liczba rozproszonych instalacji fermentacji beztlenowej, z których wiele produkuje prąd i ciepło do użytku lokalnego, rzetelne oraz spójne dane dotyczące całkowitej produkcji energii z biogazu nie są łatwo dostępne. Według danych zebranych przez IEA w 2015 roku [7], w UE przy wykorzystaniu biogazu wytworzono około 1\% energii pierwotnej i 1,9\% energii elektrycznej.

Na poziomie światowym całkowitą produkcję energii z biogazu w 2014 roku szacuje się na 80 TWh, z czego 75\% przypada na Europę. W porównaniu z wielkością produkcji biogazu surowego, uzdatnianie biogazu do biometanu prowadzono na stosunkowo niewielką skalę. W 2015 roku szacowano, że w Europie jest około 460 instalacji uzdatniania biogazu, z czego 70\% odprowadzało gaz do sieci w ilości około $1,4 \mathrm{mld} \mathrm{m}^{3}$ gazu. Stanowi to zaledwie $0,3 \%$ całkowitego zużycia gazu w Europie. Podobnie jak produkcja surowego biogazu, zakres uzdatniania biogazu do biometanu różnił się w zależności od kraju i polityki rządu. Liderami technologii uzdatniania biogazu do biometanu są Niemcy i Szwecja, w których łącznie funkcjonuje około $60 \%$ instalacji wytwarzania biometanu w Europie [8].

\section{Realizacja komplementarnego wykorzystania gazu ziemnego i odnawialnych źródeł energii}

Komplementarność technologii gazu ziemnego i energii odnawialnej można rozpatrywać w kilku aspektach: technicznym, ekonomicznym oraz środowiskowym.

Przyczyną użytkowania obu rodzajów nośników są wspólne cele w zakresie bezpieczeństwa energetycznego - zapewnienie stabilności dostawy energii, a także w dziedzinie ochrony środowiska - zmniejszenie efektu cieplarnianego. Podstawą wykorzystania odmienności technologii dla wzajemnie korzystnej współpracy jest odrzucenie traktowania gazu ziemnego i energii ze źródeł odnawialnych jako odrębnych składowych systemu energetycznego o konkurencyjnych oddziaływaniach oraz skupienie się na zbadaniu komplementarności i potencjalnej synergii na wielu poziomach.

Rozpatrując aspekty techniczne komplementarności obu nośników, trzeba podkreślić, że odnawialne źródła energii są elementami energetyki rozproszonej, czyli generacji energii przez małe jednostki wytwórcze, przyłączone bezpośrednio do sieci rozdzielczych lub zlokalizowane w sieci elektroenergetycznej odbiorcy. Model energetyki rozproszonej ma wiele zalet, do których należą możliwości wykorzystania lokalnych zasobów energetycznych, redukcja strat przesyłowych bądź możliwość produkcji energii w kogeneracji, w zależności od lokalnego zapotrzebowania na ciepło. Energetyka rozproszona zapewnia bezpieczeństwo energetyczne w większym stopniu niż energetyka scentralizowana. W przypadku źródeł niestabilnych, z których wahania energii wpływa- ją niekorzystnie na system elektroenergetyczny, szansę kompensacji stwarzają rozproszone elektrownie gazowe, wykorzystujące dostępne miejscowo dostawy gazu. W przypadku Polski elektrownie gazowe mogą pełnić funkcję regulacyjną, tym bardziej, że ich lokalizacja uwarunkowana dostępnością sieci gazowej może pokrywać się z miejscami korzystnymi z punktu widzenia energetyki wiatrowej. Analizując rozmieszczenie krajowych elektrowni systemowych, można zauważyć, że większość mocy zainstalowanych w polskim systemie elektroenergetycznym znajduje się na południu i w części centralnej Polski, w strefie niesprzyjającej lokalizacji elektrowni wiatrowych, co stwarza problemy natury eksploatacyjnej i trudności w zakresie bilansowania mocy.

Istnieje wiele możliwości integracji technologii gazu ziemnego oraz energii ze źródeł odnawialnych. Na poziomie lokalnym uzupełnianie się gazu ziemnego i odnawialnych źródeł energii może być wykorzystane w różnego typu rozwiązaniach. Wśród nich można wymienić układy hybrydowe, w których wykorzystuje się kilka rodzajów nośników energii w celu uzupełnienia wahań zasilania bądź optymalizacji kosztowej. Najczęściej stosowane są układy hybrydowe solarne, w których wykorzystanie energii słonecznej może obejmować wykorzystanie kolektorów słonecznych do produkcji energii cieplnej oraz ogniw fotowoltaicznych produkujących energię elektryczną, natomiast gaz spełnia rolę czynnika uzupełniającego w przypadku niesprzyjających warunków pogodowych. 
Inną możliwość komplementarnego stosowania gazu ziemnego i OZE stwarza wykorzystanie biogazu, gdzie możliwe jest wykorzystanie uzupełniające bądź pełna wymienność z gazem ziemnym. Gaz z fermentacji frakcji biologicznej skła-

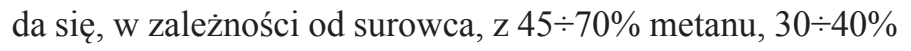
dwutlenku węgla, do $15 \%$ azotu (głównie w przypadku gazu wysypiskowego) a także zawiera niewielkie ilości siarkowodoru i innych zanieczyszczeń, przede wszystkim siloksanów (w gazie wysypiskowym i z oczyszczalni ścieków). Stosowanie surowego biogazu, tylko po usunięciu zanieczyszczeń wymaga dostosowania użytkujących go urządzeń, np. palników urządzeń spalających, jakkolwiek przy zachowaniu określonych proporcji mieszania biogazu z gazem ziemnym tak, aby parametry energetyczne mieszanki odpowiadały minimalnym wymaganiom określonym dla gazów drugiej rodziny grupy Lw i E, paliwo stanowiące mieszaninę biogazu i gazu ziemnego może być spalane w urządzeniach przystosowanych odpowiednio do spalania gazu E lub Lw bez potrzeby ich modyfikacji [15]. Dopuszczalne proporcje mieszania zależą od zawartości składników palnych w gazach użytych do sporządzenia mieszaniny, czyli metanu w biogazie oraz węglowodorów w gazie ziemnym i wahają się od kilku do kilkunastu \% obj. w przypadku konieczności zapewnienia wymienności z gazem grupy $\mathrm{E}$, a od kilkunastu do kilkudziesięciu \% obj. w przypadku mieszania z gazem Lw do zasilania urządzeń spalających gaz tej grupy.

W Polsce, niezależnie od źródła pochodzenia, biogaz nie spełnia parametrów przewidzianych dla gazu E i Lw obecnie transportowanych siecią przesyłową, określonych w PN-C04752:2011 Jakość gazu w sieci przesyłowej [6]. Udział biogazu w gazie sieciowym jest ograniczony zarówno ze względu na wymagania dotyczące własności cieplnych (wartości opałowej, ciepła spalania i liczby Wobbego) podane w Rozporządzeniu Ministra Gospodarki z dnia 2 lipca 2010 roku i PN-C-04753:2011, jak i zawartości ditlenku węgla określonej w PN-C-04752:2011 na poziomie 3\% mol/mol. Oznacza to ograniczenie wprowadzenia biogazu do gazu sieciowego do wartości kilku \% obj. W różnych państwach wprowadzanie wstępnie oczyszczonego biogazu do sieci jest ograniczone ze względu na wymagania dotyczące jakości gazu sieciowego, a dopuszczalne proporcje mieszania biogazu z gazem sieciowym zależą od zawartości składników palnych w gazach poddawanych mieszaniu oraz od dopuszczalnej zawartości ditlenku węgla i mogą sięgać kilkunastu \% obj. biogazu. W przypadku przeznaczenia biogazu do wytwarzania energii elektrycznej powszechnym sposobem jest spalanie biogazu w przystosowanym do tego paliwa silniku spalinowym, napędzającym generator prądotwórczy. Silniki gazowe mogą być również napędzane mieszaniną biogazu z gazem ziemnym przy zachowaniu określonych parametrów energetycz- nych. Innym sposobem generowania energii elektrycznej jest stosowanie turbin gazowych. Wyniki doświadczeń [9] polegających na zmianie paliwa w turbinach gazowych małej i dużej mocy sugerują, że praca takich układów jest możliwa, ale wymaga zmian w modułach oraz parametrach regulacyjnych turbiny gazowej. Wymagania stawiane przez producentów turbin w stosunku do parametrów paliw i ich zakresów zmienności są dość wąskie, co wynika z zachowania niezbędnego marginesu bezpieczeństwa oraz zmniejszenia ryzyka kosztownych napraw gwarancyjnych.

Pełną komplementarność stosowania biogazu jako źródła odnawialnego i gazu ziemnego można uzyskać poprzez uzdatnienie biogazu do parametrów gazu wysokometanowego. Oprócz usunięcia zanieczyszczeń konieczne jest usunięcie także dwutlenku węgla. Wśród metod usuwania dwutlenku węgla można wyróżnić absorpcję fizyczną, ze szczególnym uwzględnieniem płuczki wodnej, absorpcję chemiczną, adsorpcję zmiennociśnieniową, separację kriogeniczną i separację membranową [13]. Uzdatniony biometan może być bez ograniczeń zatłaczany do sieci gazowej, jak również wykorzystywany w urządzeniach grzewczych, silnikach, a także turbinach przystosowanych do spalania gazu ziemnego. Może być również stosowany w transporcie jako paliwo wymienne i uzupełniające, a nie konkurencyjne w stosunku do CNG. Pozwala to na wykorzystanie samochodów przystosowanych do zasilania $\mathrm{CNG}$, jak i infrastruktury napełniania gazem, również w przypadku sprężonego biometanu. W związku z powyższym, wymagania techniczne i warunki bezpieczeństwa użytkowania pojazdów napędzanych biometanem są tożsame z warunkami dla pojazdów z napędem CNG. Dalszemu rozwojowi tego kierunku sprzyja przede wszystkim rosnąca liczba samochodów na gaz ziemny oraz zwiększanie liczby stacji napełniania pojazdów CNG, które mogą służyć także do dystrybucji biometanu.

Jako przykład wykorzystania gazu do wsparcia funkcjonowania OZE można przedstawić układy pneumatycznego magazynowania energii pozaszczytowej - CAES (Compressed Air Energy Storage), będące modyfikacją tradycyjnego cyklu elektrowni szczytowo-pompowych z zastosowaniem turbin gazowych. W porze pozaszczytowej tania energia elektryczna jest wykorzystana do napędu zespołu sprężarek napełniających zbiornik (najczęściej podziemny - kawerny wyeksploatowanych kopalni) sprężonym powietrzem (do $10 \mathrm{MPa}$ ). W godzinach szczytu energetycznego powietrze jest uwalniane ze zbiornika, podgrzane przez spaliny wylotowe z części niskoprężnej turbiny gazowej i zasila komorę spalania turbiny, w której spalany jest gaz ziemny. Istotna oszczędność wynika z poboru taniej energii elektrycznej do napędu sprężarek, co umożliwia wykorzystanie całej wytworzonej mocy w turbinie gazowej do produkcji energii 
elektrycznej w porze szczytowego zapotrzebowania [10, 16]. Jako system wymagający stosowania gazu jako paliwa do turbiny gazowej, CAES może być traktowany jako hybrydowy układ magazynowania energii.

Kolejną możliwość współpracy OZE z systemem gazu ziemnego stwarza technologia Power-to-Gas, proces składający się z dwóch etapów - elektrolizy i metanizacji. W procesie elektrolizy wody wykorzystującym wygenerowane przez OZE nadwyżki energii, produktami są wodór i tlen w postaci gazowej. W procesie metanizacji możliwe jest uzyskanie syntetycznego gazu ziemnego (SNG - Synthetic Natural Gas) o własnościach palnych niemal identycznych jak gazu ziemnego, który może być wprowadzony do systemu gazu ziemnego bez żadnych ograniczeń bądź wykorzystany w innych obszarach, gdzie wymagana jest dobra jakość gazu ziemnego. Dwutlenek węgla do procesu metanizacji może być uzyskiwany ze źródeł pochodzenia biologicznego, np. biogazu pochodzenia rolniczego lub gazu z fermentacji osadów ściekowych. Źródłem węgla może być też dwutlenek węgla wychwytywany w procesie CCS (Carbon Capture Storage - wychwytywanie i magazynowanie węgla), w celu zmniejszenia efektu cieplarnianego, pochodzący z dużych instalacji, takich jak elektrownie i rafinerie, a także z przemysłu metalurgicznego oraz cementowego. Zagospodarowanie dwutlenku węgla łączy wykorzystanie trzech rodzajów energii - węglowej, OZE i gazu ziemnego. Wodór będący produktem pierwszego etapu procesu Power-to-Gas może być, tak jak zsyntezowany metan, traktowany bezpośrednio jako nośnik uzupełniający wobec gazu ziemnego poprzez wprowadzenie do sieci gazowej, pełniącej w tym wypadku funkcję magazynową, ze względu na jej dużą pojemność. O ile metan może być wprowadzany do sieci bez żadnych ograniczeń, o tyle dopuszczalny udział wodoru w sieci jest ograniczony ze względu na jego niekorzystny wpływ na elementy infrastruktury gazowej. W raporcie z badań zleconych przez Niemieckie Stowarzyszenie Naukowo-Techniczne Branży Gazowniczej i Wodociągowej (DVGW) podano, że dla elementów takich jak gazociągi, gazomierze, zbiorniki oraz większość elementów systemu dystrybucyjnego dopuszczalny udział wodoru, przy którym nie są wymagane prace adaptacyjne, kształtuje się na poziomie $20 \div 30 \%$. Stwierdzono także, że większość chromatografów gazowych stosowanych w gazownictwie nie jest przystosowana do analizy wodoru (przy pomiarze za pomocą chromatografów procesowych, zainstalowanych w Niemczech przed 2013 rokiem, górna granica udziału wodoru w mieszaninie jest określona na poziomie 0,2\%) [11]. Z kolei w załączniku A do normy EN 16726:2015 Infrastruktura gazowa - Jakość gazu - Grupa H [17] stwierdza się, że w niektórych częściach systemu gazowniczego jest możliwe wprowadzenie do $10 \%$ wodoru, jakkolwiek, przy stosowaniu zbiorników stalo- wych w pojazdach, zawartość wodoru w gazie zasilającym nie powinna przekraczać 2\%.

Szerszą komplementarność technologii gazu ziemnego i energii ze źródeł odnawialnych można realizować poprzez optymalizację integracji systemów elektroenergetycznego i gazowego. Wprowadzenie innowacyjnych systemów energetycznych reagujących na zmienność warunków, inteligentne sieci, sterowanie zapotrzebowaniem, magazynowanie energii i inne zaawansowane technologie zapewniają wyższy poziom kompatybilności między komponentami systemu.

Dla szybkiego reagowania na zmieniającą się sytuację w celu kompensacji niedoboru energii wytwarzanej w źródłach rozproszonych, konieczny jest rozwój inteligentnych systemów opomiarowania i sterowania sieciami zarówno w systemie elektroenergetycznym, jak i gazowniczym. Wyzwania, które stoją przed działaniem sieci gazowych w nowych warunkach dotyczą, obok spełniania podstawowej funkcji przesyłu, możliwości łatwego dołączania bądź odłączania nowych źródeł gazu, innego niż standardowy gaz ziemny, np. biogazu, biometanu, metanu z domieszką wodoru, akceptacji większej zmienności parametrów pracy (ciśnienia) w celu zwiększenia możliwości akumulacyjnych, możliwości stosowania przepływu dwukierunkowego. Możliwości wprowadzania do sieci gazowej innego rodzaju paliwa, niż gaz ziemny wiążą się z koniecznością monitorowania składu gazu w czasie rzeczywistym, stosowania efektywnych narzędzi do analiz symulacyjnych, rozliczeń opartych na jednostkach energii, inteligentnych systemów autodiagnostyki infrastruktury gazowej. Elastyczność sieci wymaga większej możliwości przełączeń w ramach istniejącej topologii, zastosowania urządzeń pomiarowych, zapewniających poprawność w większym zakresie zmienności parametrów (pomiary ultradźwiękowe) czy też monitorowania stanu sieci w czasie rzeczywistym [2].

Rozważając aspekt ekonomiczny komplementarności OZE i gazu ziemnego, należy podkreślić, że decyzje inwestycyjne dotyczące nowych projektów energetycznych opierają się na ocenie wielu czynników, takich jak koszty projektu i możliwości finansowania, dostępność zasobów paliwowych, obecna oraz prognozowana dynamika rynku, lokalne i ogólnokrajowe strategie energetyczne, przepisy dotyczące ochrony środowiska i dywersyfikacja portfela. Czynniki te charakteryzują się różnym typem, a także wielkością ryzyka, w tym związanych z finansowaniem, niepewnością w dostawach paliwa i niestabilnością cen, a także kosztami związanymi z ochroną środowiska. W większości inwestycje w energetykę nowej generacji są podejmowane na podstawie najtańszych kosztów, które nie uwzględniają w wystarczającym stopniu ryzyka reprezentowanego przez zmianę oczekiwanych przyszłych kosztów. Może to doprowadzić do stworzenia portfeli energii elektrycznej o nieefektywnie wysokim poziomie ryzyka przy danym koszcie portfela. 
Zminimalizowanie ryzyka jest równie ważne jak minimalizacja kosztów. Skuteczne metody planowania portfela, zawierające ocenę zagrożeń są drogą do utworzenia sektora energetycznego, najlepiej przygotowanego do dostosowania się do potencjalnych zmian przy najniższym ryzyku i kosztach. Jest to szczególnie cenne, biorąc pod uwagę długą ( $20 \div 60$ lat) żywotność urządzeń wytwórczych i infrastruktury energii elektrycznej, a także doświadczenie w ostatnich kilku dekadach nieoczekiwanych kierunków rozwoju przemysłu oraz gwałtownej dynamiki rynku.

Inwestycje w gaz ziemny i odnawialne źródła energii mają dość różne profile ryzyka. Ich połączenie może znacznie ograniczyć ogólne ryzyko w sektorze energii elektrycznej. Zróżnicowany portfel energii elektrycznej może być w sposób ciągły dostosowywany do zmieniających się warunków rynkowych w całym okresie użytkowania aktywów portfela.

\section{Możliwości stosowania technologii komplementarnego wykorzystania gazu ziemnego i OZE w Polsce}

Analizując dane dotyczące produkcji energii elektrycznej w Polsce [3], można stwierdzić, że w latach 2011-2015 produkcja energii elektrycznej z OZE systematycznie rosła. Jednocześnie następowały zmiany wielkości udziałów poszczególnych nośników w produkcji tej energii.

W ostatnich latach rosła przede wszystkim produkcja energii elektrycznej w elektrowniach wiatrowych. Wielkość tej produkcji w 2015 roku była ponad trzykrotnie wyższa w porównaniu z rokiem 2011. Również w odniesieniu do instalacji wykorzystujących biogaz stwierdzono wzrost produkcji energii elektrycznej. W 2015 roku wytworzono dwukrotnie więcej energii elektrycznej z biogazu niż w 2011 roku, ale wartość wyprodukowanej energii elektrycznej (906 TJ) była ponad dziesięciokrotnie mniejsza niż energii z wiatru (10858 TJ) [3]. W ostatnich latach odnotowano także w Polsce produkcję energii elektrycznej z ogniw fotowoltaicznych, ale jest to ilość niewielka (moc zainstalowana w fotowoltaice wynosi około $160 \mathrm{MW}$ ).

Perspektywy rozwoju OZE w Polsce zmieniają się dynamicznie w zależności od zmian legislacyjnych. Zasadnicze zmiany zostały wprowadzone ustawą o odnawialnych źródłach energii z dnia 20 lutego 2015 roku (Dz.U. z 2015 r., poz. 478) [20]. Przywołana ustawa o OZE przede wszystkim wprowadziła nowe zasady finansowania sprzedaży energii odnawialnej - system aukcyjny zamiast świadectw pochodzenia.

W roku $2016 \mathrm{w}$ obawie przed utratą możliwości skorzystania z systemu świadectw pochodzenia przed wejściem w życie systemu aukcyjnego, co zgodnie z ustawą o OZE zaplanowano na 1 lipca 2016 roku, przyspieszono oddanie do użytku wielu inwestycji [12]. Na koniec 2015 roku, moc zainstalowana w energetyce wiatrowej wynosiła 4,58 GW, w czerwcu 2016 roku wzrosła do 5,66 GW, by przez następny rok wzrosnąć tylko do 5,82 GW.

Przyszłość polskiego sektora energetycznego związana jest z ogólnymi wymaganiami zawartymi w pakietach unijnych, dotyczącymi celu OZE i redukcji emisji dwutlenku węgla. Przełożenie ich na cele krajowe zależy od kierunku krajowych regulacji. Niewątpliwymi celami nadrzędnymi w energetyce jest eliminacja niskiej emisji, zwiększenie efektywności energetycznej i rozwój technologii magazynowania energii.
Nie ulega wątpliwości, że niemożliwe jest zachowanie stanu obecnego polskiej energetyki. Należy liczyć się z tym, że co najmniej połowa obecnie funkcjonujących jednostek węglowych, ze względów ekonomicznych i środowiskowych, będzie musiała zostać zmodernizowana lub w wielu przypadkach, gdy będzie to zupełnie nieopłacalne, wyłączona.

Rozpatrując obecnie możliwości komplementarnego stosowania gazu i OZE, należy podkreślić, że szersze stosowanie gazu jako czynnika uzupełniającego zakłada powszechność stosowania niestabilnych OZE, dla których gaz jest nośnikiem umożliwiającym kompensowanie wahań produkcji energii. Powszechność stosowania OZE może wynikać z nakazów legislacyjnych, nakładających obowiązek ich stosowania i to w układzie wspierającym ich określoną strukturę (bądź wykluczającym uznawanie za OZE niektórych źródeł, np. biomasy określonego pochodzenia). Opłacalność w tym układzie wynika przede wszystkim z mechanizmów wsparcia przypisanych poszczególnym nośnikom i ewentualnej wysokości kar za niewypełnienie obowiązku stosowania. Trudno w chwili obecnej, ze względu na dużą dynamikę legislacyjną (od uchwalenia ustawy o OZE w roku 2015 do chwili obecnej, dokonano trzech nowelizacji, niekiedy diametralnie, tak jak w przypadku fotowoltaiki, zmieniając warunki finansowania, a przygotowane są następne nowelizacje), oceniać przy których mechanizmach wsparcia można będzie mówić o opłacalności OZE. Pewne jest, że rynek OZE reaguje bardzo szybko na mechanizmy finansowe i wsparcie określonego rodzaju OZE przełoży się na dynamiczny wzrost jego udziału w bilansie energetycznym.

Rozważając obecny stan opłacalności inwestowania w OZE, można stwierdzić, że o ile zmiany w pierwszej wersji ustawy o OZE przewidujące system taryf gwarantowanych poprawiły ekonomikę inwestycji w małą instalację fotowoltaiczną (okres zwrotu inwestycji szacowano na 6,5-8 lat), o tyle po nowelizacji ustawy w czerwcu 2016 roku [21], opłacalność małej instalacji fotowoltaicznej jest problematyczna i zależy przede wszystkim od możliwości dofinansowania instalacji. Obecnie prosument nie może sprzedawać energii, czyli na niej zarabiać, a tylko korzystać z opustów. Według Ministerstwa 
Energii zapobiegnie to tworzeniu nadmiernej liczby instalacji przyłączanych chaotycznie, które zakłócałyby funkcjonowanie sieci elektroenergetycznej, co z kolei wymagałoby interwencji państwa.

W sektorze energii z wiatru według danych Agencji Rynku Energii [1] z niemal 6000 MW zainstalowanej mocy, obecnie prawie $70 \%$ farm wiatrowych o mocy powyżej $10 \mathrm{MW}$ przynosi straty. Część właścicieli zastanawia się nad przenoszeniem farm wiatrowych za granicę. Również mniejsze instalacje (do $2 \div 3 \mathrm{MW}$ ) nie przynoszą zysku. Obniżenie opłaty zastępczej przez nowelizację ustawy o OZE z dnia 20 lipca 2017 roku [19] rozwiało nadzieje na wzrost cen zielonych certyfikatów i poprawę sytuacji wytwórców energii z OZE.

Lepiej niż w energetyce wiatrowej jest w sektorze biogazowni, który uzyskał równowagę ekonomiczną. Kolejne wsparcie dla biogazu jest przewidziane w procedowanym aktualnie projekcie nowelizacji [18].

Dla wytwórców energii ze źródeł odnawialnych w mikro- i małych instalacjach OZE, którzy wykorzystują stabilne i przewidywalne źródła energii o mocy zainstalowanej mniejszej niż $500 \mathrm{~kW}$ wprowadzone zostaną taryfy $\mathrm{Fe}$ ed-in-Tariff (FIT) i Feed-in-Premium (FIP), jednak tylko dla wybranych źródeł energii. Wytwórca energii elektrycznej $\mathrm{z}$ odnawialnych źródeł energii w małej instalacji lub w mikroinstalacji, będący przedsiębiorstwem energetycznym w rozumieniu ustawy - Prawo energetyczne, wykorzystujący do wytworzenia energii elektrycznej wyłącznie biogaz rolniczy, biogaz pozyskany ze składowisk odpadów, biogaz pozyskany z oczyszczalni ścieków, biogaz inny niż określony powyżej lub hydroenergię, będzie mógł sprzedawać niewykorzystaną energię elektryczną po stałej cenie zakupu. W ramach propozycji wprowadzenia taryf Feed-in-Premium (FIP), wytwórca energii elektrycznej z odnawialnych źródeł energii w instalacji o łącznej mocy zainstalowanej elektrycznej nie mniejszej niż 500 kW i mniejszej niż 1 MW, wykorzystującej do wytworzenia energii elektrycznej wyłącznie biogaz rolniczy, biogaz pozyskany ze składowisk odpadów, biogaz pozyskany z oczyszczalni ścieków, biogaz inny niż określony powyżej lub hydroenergię będzie mógł sprzedawać niewykorzystaną energię elektryczną innemu podmiotowi, niż sprzedawca zobowiązany i będzie miał prawo pokrycia ujemnego salda, analogicznie jak w systemie aukcyjnym. Stała cena zakupu, dla poszczególnych rodzajów instalacji odnawialnych źródeł energii ma wynosić 80\% ceny referencyjnej dla danego źródła, obowiązującej w danym roku.

Wśród źródeł energii wybranych dla tego typu wsparcia nie ma fotowoltaiki i energetyki wiatrowej, co znacząco obniża szanse na wzrost ich udziału w systemie energetycznym. W związku z tym rozwój niestabilnych OZE w Polsce jest niepewny, o trudnej do oszacowania opłacalności, choć duży potencjał, szacowany na $6 \div 10 \mathrm{GW}$ mocy przypisuje się rozwojowi morskiej energetyki wiatrowej, która może pojawić się około 2030 roku.

Wśród ryzyka, które oceniają potencjalni inwestorzy w sektorze OZE, na pierwszym miejscu w Polsce jest niepewność regulacyjna, problemem jest zmienność stanowionego prawa i brak przewidywalnych trendów w zakresie rozwoju energetyki odnawialnej.

\section{Podsumowanie}

Wzrost udziału energii odnawialnej w globalnym zużyciu energii wynika przede wszystkim z wyznaczonych celów redukcji emisji gazów cieplarnianych i zminimalizowania zmian klimatycznych. Sprzyjają mu też wyczerpywanie rezerw paliw kopalnych i dążenie niektórych krajów do ograniczenia importu energii.

Perspektywy rozwoju odnawialnych źródeł energii zależą od instrumentów legislacyjnych i co za tym idzie finansowych w danym państwie. Unia Europejska przyjęła w kwietniu 2009 roku Dyrektywę 2009/28/WE w sprawie promowania stosowania energii ze źródeł odnawialnych, wprowadzającą wiążący cel udziału 20\% energii pochodzącej ze źródeł odnawialnych w bilansie energetycznym do 2020 roku i zmniejszenia o 20\% emisji gazów cieplarnianych z poziomu z 1990 roku do roku 2020. W tzw. pakiecie zimowym z listopada 2016 roku, zobowiązano się do osiągnięcia udziału OZE w wysokości $27 \%$ jako celu wyznaczonego dla całej Unii Europejskiej do roku 2030.
Zwiększenie udziału energii odnawialnej, efektywności energetycznej, stosowanie nośników niskoemisyjnych jak gaz ziemny oraz sekwestracja dwutlenku węgla stanowią obecnie istotne możliwości dekarbonizacji sektora energetycznego, jednak opcje te często są przeciwstawiane sobie nawzajem, szczególnie jeśli chodzi o finansowanie i wsparcie. Zamiast tego, biorąc pod uwagę niepewność dotyczącą zdolności każdej z nich do osiągnięcia przewidywanych wysokości potencjału dekarbonizacji, należy stworzyć komplementarne podejście do wspierania wszystkich działań. Możliwość traktowania gazu i energii ze źródeł odnawialnych jako nośników, które mogą się uzupełniać w celu zapewnienia bezpieczeństwa energetycznego oraz redukcji emisji dwutlenku węgla może być związana z zastosowaniem różnych rozwiązań technicznych (systemy hybrydowe - solarne i gazowe, turbiny gazowe zasilane gazem ziemnym i biogazem, układy zasilane gazem do magazynowania energii pozaszczytowej, rezerwowe szczytowe elektrownie gazowe współpracujące z siłowniami 
wiatrowymi, produkcja alternatywnych paliw gazowych z biomasy - biometanu wymiennego z gazem ziemnym).

Szerszą komplementarność obu rodzajów energii można osiągnąć poprzez optymalizację integracji sieci gazowych i elektroenergetycznych, wykorzystując model sieci inteligentnych. Sieć gazowa ma duży potencjał do zapewnienia magazynowania nadmiarowej energii elektrycznej przy zastosowaniu innowacyjnych technologii przekształcających energię elektryczną w paliwo gazowe.

Perspektywy rozwoju technologii wykorzystujących gaz i odnawialne źródła energii w celu wzajemnego uzupełnienia się zależą od udziału niezrównoważonych nadwyżek energii elektrycznej z OZE w bilansie energetycznym danego kraju, wynikającego z polityki energetycznej, zakładającej określoną strukturę produkcji energii.

W Polsce działania legislacyjne zmierzają w kierunku wspierania tzw. stabilnych źródeł odnawialnych, tj. spalania biomasy i biogazu. Najbardziej prawdopodobny scenariusz zakłada, że głównym nośnikiem energetycznym pozostanie węgiel (około 50\% udziału w produkcji energii elektrycznej w roku 2050), co raczej oznacza mało dynamiczny rozwój OZE, szczególnie tych o niestabilnej produkcji. Zależy to jednak także od innych czynników, takich jak klasyfikacja biomasy jako OZE czy konieczność ograniczenia emisji dwutlenku węgla do poziomu, którego nie da się osiągnąć przy tak znacznym udziale węgla.

Prosimy cytować jako: Nafta-Gaz 2018, nr 4, s. 290-297, DOI: 10.18668/NG.2018.04.05

Artykuł nadesłano do Redakcji 13.11.2017 r. Zatwierdzono do druku 2.03.2018 r.

Artykuł powstał na podstawie pracy statutowej pt.: Analiza możliwości komplementarnego wykorzystania gazu ziemnego i odnawialnych źródet energii - praca INiG - PIB na zlecenie MNiSW; nr zlecenia: 0081/WO/17, nr archiwalny: DK-4100-0068/17.

\section{Literatura}

[1] Ciepiela D.: 70 proc. farm wiatrowych przynosi straty. Zielony biznes w ogromnych tarapatach, http://www.energetyka.wnp. pl (dostęp: październik 2017).

[2] Dzirba D.: Gazowe sieci inteligentne - opcja dla energetyki? Nafta-Gaz 2012, nr 3, s. 184-190.

[3] Energia ze źródeł odnawialnych w 2015 roku. Informacje i opracowania statystyczne, GUS, Warszawa 2016.

[4] European Biogas Agency Annual Report 2016, http://www.european-biogas.eu/2017/01/30 (dostęp: wrzesień 2017).

[5] Global Wind Energy Council (GWEC) Global Wind Report Annual Market, http://www.gwec.net/wp-content/uploads/vip/ GWEC-Global-Wind-2016-Report_April-2017_22_04.pdf(dostęp: październik 2017).

[6] Holewa J., Kukulska-Zając E., Pęgielska M.: Analiza możliwości wprowadzania biogazu do sieci przesyłowej. Nafta-Gaz 2012, nr 8, s. 523-529.

[7] IEA Bioenergy Task 37, http://task37.ieabioenergy.com/countryreports/ (dostęp: wrzesień 2017).

[8] IEA Bioenergy Task 40 http://www.bioenergytrade.org/publications/html (dostęp: wrzesien 2017).

[9] Lepszy S., Chmielniak T.: Analiza matematyczna pracy prostej turbiny gazowej po zmianie paliwa. Zeszyty Naukowe Politechniki Rzeszowskiej 2015, vol. 291, z. 87, s. 227-234.

[10] Majchrzak H., Tomasik G., Kwiatkowski M.: Wykorzystanie technologii magazynowania energii do integracji energetyki wiatrowej z systemem elektroenergetycznym. Energetyka 2012, http://www.energetyka.eu (dostęp: październik 2017).

[11] Müller-Syring G., Henel M., Köppel W., Mlaker H., Sterner M., Höcher T.: Entwicklung von modularen Konzepten zur Erzeugung, Speicherung und Einspeisung von Wasserstoff und Methan ins Erdgasnetz Abschlussbericht DVGW-Projekt G1-07-10 DBI Gas- und Umwelttechnik GmbH, Bonn (2013), www.dvgw-innovation.de/fileadmin/dvgw/angebote/forschung/ innovation/pdf/gl_07_10.pdf (dostęp: październik 2017).

[12] Nowelizacja ustawy o OZE - kto się cieszy, http://www.green-projects.pl/2017/08 (dostęp: październik 2017).
[13] Piskowska-Wasiak J.: Uzdatnianie biogazu do parametrów gazu wysokometanowego. Nafta-Gaz 2014, nr 2, s. 94-105.

[14] Renewables 2017 Global Status Report, REN 21, http://www. ren21.net/wp-content/uploads/2017/06/GSR_2017_Full_Report.pdf (dostęp: wrzesień 2017).

[15] Siuda T., Wójtowicz R.: Badania możliwości wspótspalania biogazu rolniczego i $L N G$ lub $L P G$ w urządzeniach użytku domowego oraz w urzadzeniach do zastosowań przemysłowych. Nafta-Gaz 2016 nr 9, s. 747-754, DOI: 10.18668/NG.2016.09.10.

[16] Wojciechowski H.: Technologie magazynowania energii. Cz. II. Instal 2017, nr 3, http://www.informacjainstal.com.pl (dostęp: wrzesień 2017).

\section{Akty normatywne i prawne}

[17] EN 16726:2015 Infrastruktura gazowa - Jakość gazu - Grupa H

[18] Ustawa o zmianie ustawy o odnawialnych źródłach energii oraz niektórych innych ustaw, projekt, https://legislacja.rcl.gov.pl/ projekt/12299905 (dostęp: październik 2017).

[19] Ustawa z dnia 20 lipca 2017 o zmianie ustawy o odnawialnych źródłach energii (Dz.U. z 2017 r., poz. 1593).

[20] Ustawa $z$ dnia 20 lutego 2015 r. o odnawialnych źródłach energii (Dz.U. z 2015 r., poz. 478).

[21] Ustawa z dnia 22 czerwca 2016 r. o zmianie ustawy o odnawialnych źródłach energii oraz niektórych innych ustaw (Dz.U. z 2016 r., poz. 925).

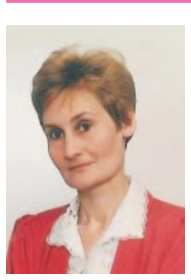

Mgr inż. Julita PISKOWSKA-WASIAK

Starszy specjalista badawczo-techniczny w Zakładzie

Technologii Oczyszczania i Nawaniania Paliw.

Instytut Nafty i Gazu - Państwowy Instytut Badawczy

ul. Lubicz 25 A

31-503 Kraków

E-mail: piskowska@inig.pl 